\title{
ISLAMISATION AS LEGAL INTOLERANCE The Case of GARIS in Cianjur, West Java
}

\author{
Ratno Lukito \\ Sunan Kalijaga State Islamic University (UIN) Yogyakarta, Indonesia \\ email:ratnolukito@yahoo.com
}

\begin{abstract}
In its endeavour, Islamization projects done by some Muslim organisations in Indonesia can lead to certain treats of intolerance, especially to those rejecting the missions wrought about in the movements. Using qualitative approach, this paper tries to analyse the legal Islamization programs undertaken by Gerakan Reformis Islam (GARIS) in Cianjur, West Java, since their inception in early 2001 and its inclination to various intolerant attitudes towards others. The movement of Islamization is probed on the basis of the three main GARIS projects, namely, reviewing the draft of Indonesian penal law, engaging contraChristianization movements and the struggle against Ahmadiyah. Describing the movement, one will see how the idea of legal Islamization is carefully and persistently moulded in the field to make it so fluid and adequate to accomplish a purpose. What seems appearing in this phenomenon is not a theoretical legal quandary but more a political one, as legal Islamization is in its practice more sensed as a political movement than that of law.

[Dalam praktiknya, gerakan Islamisasi yang dilakukan oleh beberapa organisasi Islam di Indonesia dapat memunculkan tindakan intoleransi, utamanya bal itu menimpa mereka yang menolak gerakan tersebut. Dengan menggunakan pendekatan kualitatif, paper ini berusaha untuk menganalisis program-program Islamisasi bukum yang dilakukan oleh Gerakan Reformis Islam (GARIS) di Cianjur, Jawa Barat sejak mula berdirinya organisasi ini di awal 2001 dan kecenderungannya kepada perilaku intoleransi kepada kelompok lain. Gerakan Islamisasi dari GARIS ini dikaji berdasarkan pada
\end{abstract}


tiga program mereka yang paling utama yaitu: usulan perbaikan terbadap draf amandemen bukum pidana Indonesia, gerakan perlawanan terbadap kristenisasi, dan perlawanan terbadap kelompok. Ahmadiyah. Melalui kajian yang mendalam terhadap organisasi ini, kita dapat melihat bagaimana program Islamisasi hukum tersebut dilakukan dengan kesungguhan di lapangan sehingga dapat meraih hasil sesuai dengan yang dicanangkan. Apa yang dapat kita lihat dari fenomena ini sejatinya bukanlah pergumulan teori bukum namun lebih sebagai perhelatan politik, karena pada praktiknya gerakan Islamisasi hukum itu lebih menonjol sisi gerakan politiknya ketimbang bukumnya.]

Keywords: Legal Islamization, religious intolerance, GARIS, Indonesian penal law, contra-christianization, Ahmadiyah

\section{A. Introduction}

Referring to Article 2 Paragraph 2 of Declaration on the Elimination of All Forms of Intolerance and of Discrimination Based on Religion or Belief, intolerance can be defined as any acts of 'distinction, exclusion, restriction or preference based on religion or belief and having as its purpose or as its effect nullification or impairment of the recognition, enjoyment or exercise of human rights and fundamental freedoms on an equal basis.' ${ }^{1}$ Thus, such actions as not accepting a community or expressing or exposing hate to other community based on differences in religion or belief can certainly be referred as the act of intolerance. Based on such a definition, this paper will be devoted to discussing the movement of legal Islamisation undertaken by Gerakan Reformis Islam (GARIS) in Cianjur, West Java, the movement of which has given the result of various intolerant attitudes to others with differences.

In this paper, the discourse of legal Islamisation is studied from the perspective of its practical aspects, i.e., how the idea is developed, campaigned and impregnated throughout the Muslim society of Cianjur,

* I should express my gratitude to Prof. Martin van Bruinessen for his review and suggestions to the draft of this paper, without which the ideas outlined in this article may not be legible. Any mistakes, however, are the sole responsibility of the author.

${ }^{1}$ On the text of the declaration see, $A / R E S / 36 / 55$. Declaration on the Elimination of All Forms of Intolerance and of Discrimination Based on Religion or Belief (10 Feb 2017), http://www.un.org/documents/ga/res/36/a36r055.htm, accessed 10 Feb 2016. 
West Java, and thus giving the result of intolerant actions. Using a qualitative method, the struggle to Islamize everyday lives of the people is chosen as a means to see the dialectics between Islamic law and society. This paper will concentrate on seeing how the efforts of Islamisation conveyed in GARIS programs have brought oppressions and intolerance to ideas, actions, people or groups having a different understanding of the certain (legal) interpretation or belief.

In so doing, the paper will be divided into three cohorts: first, understanding the background and actors behind the rise of GARIS movements in Cianjur; second, the structure and character of the organization; and third, the struggle of Islamisation conveyed in the three grand programs implemented in the field so far, namely, the review of the draft of Indonesian penal law, contra-Christianization movement and the struggle against Ahmadiyah. The data pertinent to the study was taken mainly from in-depth interviews with the main actors of the organisation, involvement in some GARIS activities, as well as general observation in the lives of some GARIS activists during the field research in Cianjur intermittently during the months of 2009 and 2013.

\section{B. Background of GARIS}

It is indeed not clear what the date exactly GARIS was established, but its formation was certainly inseparable from the context of reformation movements rising steadily in Indonesian politics since the mid of $1998 .{ }^{2}$ It was a Muslim politician having the interest to establish a local hardliner group in Cianjur, West Java, who started this mass organisation. Named Chep Hernawan, originally from Cianjur and once a leading figure of an Islamic party, Partai Bulan Bintang (Crescent Star Party, PBB) ${ }^{3}$ when it was established initially in 1998 . Hernawan himself did not give so much interest to the organisation he initially founded in

${ }^{2}$ See also on GARIS in comparative studies with other Islamisation movements in other provinces in Jamhari Makruf and Iim Halimatussa'diyah, Shari'a and Regional Governance in Indonesia: A Study of Four Provinces, SSRN Scholarly Paper, no. ID 2459826 (Rochester, NY: Social Science Research Network, 2014), pp. 1-15.

${ }^{3}$ It is important to note here that PBB was the party claiming to be the embodiment of the Masyumi tradition. See Bernhard Platzdasch, Islamism in Indonesia: Politics in the Emerging Democracy (Singapore: ISEAS Institute of Southeast Asian Studies, 2009), p. 34. 
1998 as he seemed more busied himself in Jakarta with his activities as the treasurer of the party. Yet, it was not until 2001 when he finally turned his focus to develop further the organisation since the environment in PBB was not conducive in his feeling to continue the career in national politics. He was so disappointed with the party, especially in its failure to assure the parliament bolstering the idea of enlivening the Jakarta Charter in the amended 1945 Constitution. He was also once expressing his dissatisfaction with the leader of the party, Yusril Ihza Mahendra, seen as not so sincere in the struggle of legal Islamisation in Indonesia and even more enthusiastic toward individual material benefits, especially as his later appointment as the Ministry of Law and Human Rights. ${ }^{4} \mathrm{He}$, therefore, decided to step down from PBB and continue his struggle in his home base, Cianjur. Upon his return, GARIS was thus rejuvenated after some years of no activities.

GARIS was first designed as an answer to the need of some Muslim hardliners such as Anwar Haryono and Husein Anwar (both then the leading figures of Dewan Dakwah Islamiyah Indonesia, DDII) to prevent the coming of a number of secular groups leaning towards socialism and communism in the new political landscape of Indonesia. Hernawan was indeed in his younger age an activist of Gerakan Pemuda Islam (Muslim Youth Movement, GPI) having a deep concern to the possibilities of reappearing communist groups in the country. ${ }^{5}$ The establishment of GARIS was, therefore, idealised as a means to block the new communism in all its forms. This is why GARIS is characteristically closer to radical religious groups concerned with neo-communism and liberalism in Indonesia. Thus, although it is local in its origin, the character of GARIS and its activities and the way to disseminate their missions is inseparable from the country's radical groups in general. ${ }^{6}$

\section{${ }^{4}$ Chep Hernawan, interview (8 May 2009).}

${ }^{5}$ DDII and GPI are both the Muslim organisations rooted in Masyumi tradition. Many see DDII as the leading custodian of the Masyumi legacy, established in 1967. See Platzdasch, Islamism in Indonesia, p. 34.

${ }^{6}$ It needs to remember that Masyumi tradition is always strong in West Java. Many traditionalists in the region maintained their membership in Masyumi weathering the political changes occurred in other Muslim areas in Java. It seems logical here that what GARIS had developed in its movements was an attempt to revive majority Masyumi traditions in the region. 
The reactivation of GARIS in 2001 was really in conjunction with the political situation of Cianjur. This regency was at the time led by a devout Muslim politician well known for his concern to implement many Islamic values in everyday lives of the people. Wasidi Swastomo was just elected as a regent of Cianjur when Chep Hernawan returned to his home village. Swastomo was a kind of literalist whose thinking of religion was influenced by his religious teacher, Kyai Dadun Kohar, the well-known figure of Persatuan Islam (Islamic Unity, Persis) from Sukabumi, West Java. It is thus not a surprise that many of Swastomo's programs were certainly coincident with the mission brought about by Hernawan since his previous political involvement in PBB, i.e., the struggle to involve the state government in the implementation of Islamic law. The core value of Hernawan's struggle is the unity of state and religion, and this should be reflected in direct involvement of the government in strengthening Islamic law in the life of the people. And what Swastomo had shown since his initial office was his concern to demolish many practices in the society seen as transgressing the principles of Islamic beliefs.

One of the core programs proposed by Swastomo at the time was the project of Shari'ah implementation, called later as 'Gerbang Marhamah', the acronym of the phrase 'Gerakan Pembangunan Masyarakat Berakblakul Karimab' (the movement for developing a society with noble characters). ${ }^{7}$ The program itself was designed by the belief that the Shari'ah implementation project is needed as the perfect tool to improve the whole life of the people in Cianjur. The actualization of Islamic law in their lives was meant as the tool for social engineering where the local government directly involved in promoting Islamic injunctions and establishing moral values within the community. ${ }^{8}$ Swastomo himself was so confident at the time that with the adoption of his Shari'ah project the

${ }^{7}$ It is good to note also that the word "Marhamah" in Arabic means as the state of being pity, compassion, merciful, sympathy, not disposed to severity. "Gerbang Marhamah" can thus be translated as the gate of merciful, compassion, or sympathy. Imagining Cianjur as the place where people can achieve a state of being merciful and compassion. See J. Milton Cowan, Arabic-English Dictionary: The Hans Wehr Dictionary of Modern Written Arabic, 3rd edition (Ithaca, NY: Spoken Language Services, 1976), p. 332.

${ }^{8}$ Michael Buehler, "Shari'a and Social Engineering: The Implementation of Islamic Law in Contemporary Aceh, Indonesia by R. Michael Feener (review)", Indonesia, vol. 98, no. 1 (2014), p. 150. 
executives will work more effectively and thus banishing the corruptive tradition still colouring the bureaucracy.' Indeed, the word 'Gerbang Marhamah' was easily spreading all over the regent, commemorating the long-held imagination of Cianjur as an Islamic region in the midst of beautiful and peaceful Sundanese enclaves in West Java.

This kind of program indeed invited a lot of support from many Muslim organisations in Cianjur, notably from Muslim hardliner groups such as GARIS. Swastomo had therefore been successful in attracting political support from those Muslim organisations existing in the society. In its development, the phrase 'Gerbang Marhamah' had become such kind of noble label for the city of Cianjur, expressing imminently the commitment of the whole people to implement the teaching of Shari'ah in their everyday life. As a follow up to the Islamisation program, the regent then issued a Decision Letter No. 36 of 2001 impregnating the establishment of the Foundation for the Study and Development of Islam (Lembaga Pengkajian dan Pengembangan Islam, LPPI), equipped with the rights to translate the grand ideas of 'Gerbang Marhamah' into more practical rules and principles which would be used as guidance for executives in the process of law-making in line with the teaching of Shari'ah. ${ }^{10}$

Although the government was successful enough to promote the 'Gerbang Marhamah' program throughout the regency, not all people understand the concept. Many were even sceptical towards the program, seeing it as more political in colour than a sociocultural-driven, in spite of the mass support for the need of enhancing moral virtues of the people. ${ }^{11}$ Yet, this kind of project is certainly in conjunction with GARIS commitment to bolster the implementation of Islamic law within the life of the people. Since the term 'Shari'ah' itself as understood by GARIS members is the religious law governing the members of the Islamic

9 "Cianjur Semakin Tampak Religius", Kompas, p. 8. As cited in Buehler, "Shari'a and Social Engineering", p. 150.

${ }^{10}$ Chep Hernawan, interview (23 Aug 2009). The socialization of the Shariatization project has basically been undertaken in three basic programs: Preaching, education and economy. See Rohmat Suprapto, Syariah "Kacapi Suling” \& Syariat Progresif: Pergulatan Politik dan Hukum di Era Otonomi Daerah (Yogyakarta: Samudra Biru, 2011), pp. 70-120.

${ }^{11}$ Suprapto, Syariah "Kacapi Suling” \& Syariat Progresif, pp. 121-59. 
faith as derived from the religious precepts of Islam, particularly the Qur'an and the Hadith, the program is not but a panacea to augment GARIS socio-political status. It is clear that what GARIS understands as 'Shari'ah' is essentially a canonical law, prescribing both religious and secular duties all Muslims should obey totally in their lives. In this way, we can thus see that GARIS members' understanding about Shari'ah follows the traditional perspective of many Muslims in which as a law Shari'ah comprises both theological and legal aspects. This legal cognition has certainly worked well to start with the Islamisation projects promoted by the local government.

The political situation of the regent was thus very conducive for Hernawan to heal his broken political career in the national arena. At least with reactivating GARIS that his old ideals can be realised benefiting local movements, in the hope that it can finally reach the wider scope of Islamisation to the whole nation. That is why many of GARIS activities in its early phase of reactivation were reflecting Hernawan's ideas of Islamisation, which were difficult to be implemented by way of national institutions such as PBB or any other political parties. He thus focused his Islamisation programs mainly on some local issues related to the implementation of Islamic teachings in the grassroots. In this way, GARIS could become the partner of the local government programs of 'Gerbang Marhamah' since both have the same fundamental concern for avoiding people from any moral problems and other un-Islamic practices. In so doing, GARIS could use the programs of 'Gerbang Marhamah' as a means to bolster its missions of Islamisation, with the result that it could get a positive image of an organisation having a good mission to succeed the government programs of development. Thus, the two can work in the way of symbiosis mutualism principles.

\section{The Character and Structure}

Since its first establishment in 1998, GARIS reflects very much the character of a hard-line organisation preferring to use violent behaviour as its main approach. And this certainly is influenced by the attitude of its founder, Hernawan, in his encounters with many different values in society. He explained that in facing many un-Islamic practices, Muslim 
should be firm and strong to oppose. ${ }^{12}$ He quoted one Prophetic tradition that when someone sees a wrongdoing, he/she should use the hands to change it, if not use the tongue, or at least oppose it with the heart, thus reflecting the weakest believers. ${ }^{13}$ It is mainly based on the teaching of this hadith that Hernawan tends to use zero-tolerant attitude in facing many practices in the society seen as transgressing the principles of Shari'ah. It is thus not a surprise that since its early commencement, GARIS is very well known for its harsh approach to implementing many programs of Islamisation. Common people in Cianjur therefore usually connote GARIS as 'Organisasi Anti Maksiat' (the organisation of anti-wrongdoings), reflecting the image of GARIS as an organisation focusing their activities to bulldoze any bad behaviours committed by people. This is what we would like to categorise GARIS as one of few organisations focusing its struggles on using 'hard methodology' of legal Islamisation. This means that the main method of Islamisation employed in this organisation tends to close with violence activities; the approach is more confrontational and less dialogue. Many of GARIS activities are therefore not taken in the form of oral debate or open discussion, but more going down to the field fighting the contender physically and often resulted in destructive outcomes.

It is not without reason therefore that many have recognised GARIS as another kind of the well-known Islamic Defense Front (Front Pembela Islam, FPI) existing in Cianjur. In this case, Hernawan admitted himself that FPI is kind of mentor to GARIS. ${ }^{14}$ Many of his approaches implemented in GARIS are a reproduction of the method of struggle used by FPI. The zero-tolerant attitude in facing wrongdoings viewed as transgressing the basic tenets of Islam has become the sole driver for those hardliners to continue the movements of Islamisation. Thus, although GARIS and FPI have no structural relations, they are substantially the same and can be grouped into one family of hardliners focused so much on moral and theological problems existing in the

${ }^{12}$ Chep Hernawan, interview (20 Jul 2009).

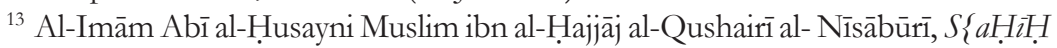
Muslim, Hadith No. 70. ('Man ra'ā minkum munkaran falyughayyir biyadihi fain lam yastați' fa bilisānihi fain lam yastați' fa biqalbihi wa dzālika 'ad \} 'aful īmān').

${ }^{14}$ Chep Hernawan, interview (25 Aug 2009). FPI is a vigilante Islamist group, established in 1999. 
society. This is what seemed to make non-GARIS members, either Muslims or not, in the regent feeling threatened to GARIS behaviours and attitudes in undertaking the Islamisation projects. That is why, it has apparently had also a clumsy relationship with such other bigger Muslim organisations as Muhammadiyah or Nahdlatul Ulama $(\mathrm{NU})$ in the region, as the two seems not to support such a frantic method of preaching Islam. Many people, especially those non-Muslim minorities, rebuffed to talk openly about this organisation, depicting ostensibly their real aversion as well as disagreement with GARIS missions. ${ }^{15}$

The significant influence of the founder of this organisation is certainly not without consequence. Almost all activities are done with Hernawan as the sole funding party. ${ }^{16} \mathrm{He}$ dominates the discourse since he the one who subsidises a lot of GARIS activities. It is not easy indeed in such a poor society as in Cianjur to find a wealthy people willing to finance many activities done based on certain religious beliefs. In this case, what Hernawan has done is just reflecting an example of how a few rich people in the midst of a poor society have tried to build an influence using all means possible. If so, it might not be without reason that Hernawan has persistently used his capital to continue his influence in GARIS. And he seems successful with this motive although with a dire consequence inflicted to the structure of the organisation.

Indeed, Hernawan's influence affects greatly to the structure of GARIS. The domination of Hernawan as the sole founder reflects on his role as the top leader of the organisation having all rights of decisionmaking. Although the board of executive comprises of some members, the persons fulfilling the position are all elected directly by Hernawan based upon their closeness and historical, personal relations. ${ }^{17}$ We can see therefore that the executive members consist of those whose trust is not based on their merits but a personal relationship with the top leader. Since

15 One Christian man indeed showed his feeling of rebuff when asked about GARIS movements. Christian figure, interview (10 Aug 2009).

${ }^{16}$ It is not clear how could Chep Hernawan provide the finance of the whole GARIS activities. One informant told the author that his funding was found basically from his father in law, named Haji Dapet, who was before the local rich businessman and a Persis figure, and also once an unsuccessful candidate of Cianjur regent. Pranoto Iskandar, interview (8 Feb 2017).

${ }^{17}$ Hernawan, interview (25 Aug 2009). 
its first formation in 1998, Chep Hernawan remains the chief executive of GARIS, while Yayan Hendrayana as vice director and Sugianto as a spokesperson. ${ }^{18}$ These two last members are the old friends of him since he was still a student of the Institute for Islamic Propagation (Perguruan Tinggi Dakwah Islam, PTDI) Tanjung Priok, Jakarta. To complete the structure, Hernawan also invited a number of well-known hardliners in the country to fulfil the position of the steering committee of the organisation (Dewan Syuro), they are Abu Bakar Baasyir, Abdul Kadir Djaelani, Ahmad Sumargono, and Kholil Ridwan. Hernawan explained that he owes so much from those persons he views as his advisers and example, especially on their commitment to uphold the teaching of Islam and their opinion of the method of Islamisation.

As an organisation built upon the personal relationship with the founder, not much can be said regarding the structure and the culture developed in GARIS, except for the fact that all organisational mechanism is created by a personal relationship between the top leader and the members. We cannot see therefore that GARIS has some common traditions normally practised in a mass organisation such as Congress to create a constitutional law of the organisation, or having a common election to elect board executive members, etc. The structure already built in the organisation since its initial formation is still maintained and seems to exist there until the long future.

The structure of the organisation is also strengthened through active involvement of the members. As other radical groups in general, the membership of GARIS can be attained through a relatively loose process. Someone can become a member of GARIS without certain rigid and complicated bureaucratic process. Anyone can just attend or involve in certain activities of the organisation to get a full membership. Let alone if the person has close personal relationship with the leader. We can say that filtering mechanism seems to work here through the involvement of the person in any activities organised by GARIS. ${ }^{19}$ The principle seems thus to work that the more the one involves in their activities, the more the one will be accepted as a member of the organisation.

${ }^{18}$ Ismail Hasani, Radikalism Agama di Jabodetabek \& Jawa Barat: Implikasinya terhadap Jaminan Kebebasan Beragama/Berkeyakinan (Jakarta: Publikasi Setara Institute, 2001), pp. 127-28.

${ }^{19}$ Chep Hernawan, interview (26 Jul 2009). 
Currently, GARIS has claimed to have thousands of members throughout Cianjur and other cities in West Java. One respondent explained that in Cianjur alone GARIS has succeeded to recruit no less than twenty-eight thousands of members actively involved in their activities, while in Sukabumi, there are about five thousand persons ready to join any GARIS's programs of Islamisation. ${ }^{20}$ It is not easy however to get evidence of this data as a written record of the membership cannot be found in GARIS central office in Cianjur. As a rather loose organisation, GARIS seems not to recognise the membership based upon the modern way of recording but more on the fact of their involvement in every activities and program, and more importantly on their common religious understanding and sincerity to take part in the struggle of Islamisation.

\section{The Struggle for Legal Islamisation}

As said earlier, the main reason for the founder of GARIS to establish the organisation in Cianjur is basically to continue his struggle to succeed the programs of Islamisation which had failed through a national political party. There was a hope that through GARIS the broken ideals could be remedied and the objectives of the Islamisation could finally be achieved even if the project should be done in a merely local and smaller scope. Notwithstanding its different provision, the purpose of the struggle thus remains the same, i.e., to uphold Islamic values in the life of the people and this can be done if Islamic law can be implemented fully in the society. Although undertaken in such a localised arena, GARIS projects of Islamisation have a similar substantive agenda. What makes GARIS looks distinct is its concern on religious practices in micro level of the society. Thus, the model of the struggle here is one of the grassroots, and the Islamisation of law undertaken therein benefits more the bottomup approach where the involvement of the members is used maximally to bulldoze any practices in the society viewed as transgressing the principles of Islamic law. Thus what concern much here is not the application of the law from the macro level of the state but more that of the micro level where the teachings of Shari'ah should appear in everyday lives of the people. Phrased differently, GARIS activities are mainly focused on the process of legal application and not that of law-making, although

${ }^{20}$ Hasani, Radikalism Agama di Jabodetabek \& Jawa Barat, p. 125. 
the two seems, in fact, inseparable. This seems in line with the character of GARIS as a local organisation confining its struggle on local agenda; the choice of focus is therefore taken based on the character and scope of the organisation. Yet, this does not mean that one can undermine this organisation due to its locality. A number of GARIS activities have indeed wider impacts beyond Cianjur area so much as creating its label as one of the most radical Muslim groups in West Java.

As a radical group preferring to use the hard methodology of legal Islamisation, GARIS has so far focused on the problem of Islamic law in Indonesian secular legal system. The main concern seems here not on the theoretical aspects of the law but the legal application, especially those related to the position of Islamic law. Thus, radicalism appears mostly as a primary method in their struggle to revive the Islamic legal application in the society, ignoring the fact that Islamic law is not the sole legal tradition in the country. Differently put, GARIS does not put their attention on how Islamic law can be applied in the midst of legal plurality, but more on the need of every individual Muslim to consistently apply the religious law. Since its first inception, there are at least three legal issues GARIS has put their concerns in the struggle of Islamisation: the draft of Indonesian penal law, Christian proselytization, and Ahmadiyah school. The three cases deserve to be discussed here since their relationship with the issue of implementing Islamic law in the milieu of national secular law. The first issue of drafting Indonesian penal law touches the issue of how to apply Islamic penal law in such a secular country. The second, Christianization deals with the problem of how to regulate religious preaching in a religiously pluralistic society of Indonesia; while the third on Ahmadiyah case relates specifically to the issue of varied religious denominations existing in the country. The three cases will be discussed in the following pages as an example of how as a non-state institution GARIS has consistently undertaken the project of legal Islamisation during the last ten years.

\section{Reviewing the Draft of Indonesian Penal Law}

This activity seemed to be the first entry point of GARIS reactivation in 2001. Since the main reason of Hernawan retreat from the national arena was due to the failure of $\mathrm{PBB}$ for consistently struggling to 
implement the mission of building Islamic penal law system in Indonesia, the localised approach activity focused on such a mission had indeed become the essential program for GARIS in Cianjur. Although the scope of the project was kept as a small activity as it would only involve limited figures in Cianjur and other surrounding cities in West Java, the impact of such activity was what believed to have inspired GARIS since its early commencement. The point is thus not the quantity but the quality that is hoped to give the maximum result for arriving at the ideal of legal Islamisation in Indonesia. ${ }^{21}$

Many jurists in the country believe that the heydey of legal Islamisation in Indonesian history was started when President Soeharto in his last decade of power tried actually to create national regulations, adopting many aspects of Islamic legal teachings. Even if it was not so many in number, a number of Islamic legislative and executive regulations were successfully made to reassure the implementation of Islamic law in the public arena. ${ }^{22}$ This became the starting point for the Islamisation movement to continue when the regime was toppled down, and the new Reformation Order came to the surface colouring the political scene of the country. Habibie's short time presidency had even been recorded as the most pious period in the post-New Order era due to its rather massive product of Islamic law using the vocabulary of state law. ${ }^{23}$ Whatever the achievement that can be drawn in these big efforts of legal Islamisation, one thing, however, remains unreachable, i.e., the implementation of Islamic penal law in the system of national law of the country. It is groundless to believe that the objective of Islamisation is successfully achieved simply by the number of such Islamic acts and regulations without factually capable of substantiating Islamic penal law

${ }^{21}$ This might be comparable to the so-called 'Islamisation from Below' as what explained lately by Tim Lindsey, see his Timothy Lindsey, Islam, Law and the State in Southeast Asia, vol. I (London and New York: I.B. Tauris, 2012), pp. 15-22.

${ }^{22}$ For instance, Law No. 7 of 1989 on Religious Courts; Presidential Instruction No. 1 of 1991 on the Compilation of Islamic Law.

${ }^{23}$ See on this in Ratno Lukito, Legal Pluralism in Indonesia: Bridging the Unbridgeable (London and New York: Routledge, 2013), pp. 116-121. In a relatively short period of Habibie's presidency, there were 69 new laws promulgated, some of them directly affected to the implementation of Islamic law, such as: Law No. 10 of 1998 on Islamic Banking; Law No. 17 of 1999 on the Management of the Islamic Pilgrimage; and Law No. 38 of 1999 on the Management of Zakat (Islamic Charity). 
teachings in the secular legal system of the country. It depends on how we define the achievements indeed, but one proposition seems clear here that the essence of the struggle relies upon the substantiation of Islamic penal law in the public arena. On the top of the pyramid of legal Islamisation, thus, the Islamic penal law system lays. The success of legal Islamisation in the country will automatically be truncated whenever the penal law does not exist. ${ }^{24}$

Hernawan seems to believe in such a principle. The implementation of Islamic penal law in the everyday lives of the people is the mainstay of the struggle for Islamisation. He, therefore, was so enthusiastic about the idea to continue the movement even if the condition did not allow him to work it out by way of national apparatus. If he should be in disappointment with the Ministry of Law and Human Rights (at the time his old close colleague in the struggle, Yusril Ihza Mahendra), he believed that the path towards Islamisation of penal law should still be continued carefully. And, his zeal of effort was strengthened considering the abundant resource persons in Cianjur and surrounding cities in West Java well versed with the knowledge of Islamic penal law to back up the theoretical aspects of the tradition. To realise this project, Hernawan got so much help from one local Islamic expert (Kyai) well known for his expertise in many classical books of Islamic penal law (fiqh jinayah).

The person in concern was Kyai Dede Abdullah, living in a small village with a number of students devoted themselves to study Islam in his small boarding school in Maleber, Cianjur. Not much could be described this kyai except for his resilience to place Islamic law in real life of the people. He once explained that a number of state officers from the Ministry of Law and Human Rights in Jakarta came to him to consult many aspects of Islamic law to be used as a raw material for the government's programs of drafting certain laws and regulations. ${ }^{25}$ It is therefore very strategic for Hernawan to approach him asking for assistance to succeed the program of Islamic penal law. Hernawan realised that his knowledge on the substantive aspects of the penal law was not adequate; what he had was only a passion and enough funds to support the idea of the struggle. ${ }^{26}$ His willingness to involve the kyai in this program was certainly an effective step towards realising the program of Islamizing penal law in Indonesia.

${ }^{24}$ Daniel E. Price pinpointed five areas of law touching the aspects of Islamisation efforts, namely: personal status, economic and business, religious practices, criminal law, and governing system. See Daniel E. Price, Islamic Political Culture, Democracy and Human Rights: A Comparative Study (Westport, Connecticut: Praeger, 1999), p. 145..

${ }^{25}$ Interview with Kyai Dede Abdullah (25 Jun 2013).

${ }^{26}$ Chep Hernawan, interview (24 Jun 2013). 
Realising the history of penal law in Indonesia, GARIS agreed that the best way to start the program of Islamisation was to infuse abundant values of Islamic penal law in the official system of law of the country. ${ }^{27}$ This is believed to become a good leeway for step-bystep building Islamic penal law system in such a pluralistic country of Indonesia. In so doing, the most effective program to undertake was by reviewing the draft of the new penal law that had long been prepared by the government. By benefiting many Islamic experts (Ulama) living in Cianjur and its surrounding areas, Hernawan, therefore, was able to gather a lot of ideas on how to start implementing the program. Thus, with the help of kyai Dede Abdullah, GARIS organised a meeting of those Ulama concerned with the issue of the draft of the penal law. The meeting was held during the fasting month of Ramadan in a small boarding school, Alawiyyin, in Maleber, Cianjur from November 26 to December 3, 2001. The formal meeting was then continued for a week, 3-8 December 2001, gathering a smaller team of Ulama specially undertaken to discuss furthermore and formulate a review of the draft of the penal law. ${ }^{28}$ The meeting was then totally held for full two weeks in the holy month of Ramadan when all Muslims did the obligatory daily fasting during the month. Interestingly, this activity was conducted in cooperation with the Ministry of Law and Human Rights and the local government of Cianjur. Many Ulama from Sukabumi, Cianjur, Garut and Tasikmalaya were recorded to have attended this meeting, making this event as the first of its kind successfully organised by such a local mass organisation as GARIS.

Reading page by page the meeting report, one will get a sense of the complexity of the debate involved to review the draft of the penal law was. Resulted from a hard effort of the government since the reformation era to answer the national need for having self-made penal law system, the draft of the penal law itself is very long, consisting of no less than 32 chapters and 644 articles. Many believe that since independence this country has never been able to produce independently its penal law system rooted from its values and traditions. The current Code of Penal

${ }^{27}$ Hernawan, interview (25 Aug 2009); Kyai Meleber, interview (7 May 2013).

${ }^{28}$ Usulan Perubahan RUU KUHP Hasil Musyawarah 'Alim Ulama se Jawa Barat yang Diwakili oleh Kabupaten Sukabumi, Cianjur, Garut, Tasikmalaya, Cianjur, 10-18 Ramadan 1422-26 Nopember-3 Desember 2001 (Cianjur, 2001), p. iii. The document is with the author. 
Law (Kitab Undang-Undang Hukum Pidana) that has been working since early independence era is an adoption of the Dutch colonial penal law code as emanated in the Wetboek van Strafrecht (WvS), Staatsblad 1915 No. $732 .{ }^{29}$ The need of penal code believed as originally derived from national ideals and values thus becomes a national agenda unreachable yet until the current era, the draft of the penal law is therefore hoped to become an answer for such a longing need in the system of law of the country. The impediments involved in the creation of a new unified penal code in Indonesia are varied, however, one of the biggest factors comes from Muslims in the country who are so persistent to put forward the teachings of Islamic penal law tradition as the main source in the process of making the draft. This problem is, in fact, a latent one since the dominance of Islamic law tradition in such a country with majority Muslim population can never be neglected in the process of national law making.

During the two weeks of the discussion, those Ulama were so earnestly debating the content of the draft. As clearly explained in the introduction of the report, there is a common belief among them that the current penal code cannot, in fact, hinder Indonesian people from many crimes still existing in the society. ${ }^{30}$ This creates a situation where the country has never been able to free itself from bad situations haunting many aspects of life. They are assured that Islam can offer the remedy of those critical situations, i.e., by offering a distinct penal law tradition that can guarantee the order of life where justice and welfare of the people are always upheld. They, for example, putatively proposed that the draft of the penal code that will be submitted to the People Assembly in Jakarta should maximally incorporate Islamic penal law teachings. Their main task, therefore, is to make a review of the draft and propose some comments and suggestions based on their expertise and understanding of the Islamic penal law. ${ }^{31}$

On the cognitive aspects, the meeting had successfully brought about Islamic theories of penal law idealised to be incorporated in the

${ }^{29}$ This code was basically the copy of the penal code in the Netherlands, which was in essence the Old Dutch and Roman penal law that went as far back as 1642. The uniform Criminal Code (Wetboek van Strafrecht) itself was based on the Royal Decree No. 33 of October 15, 1915 in S.1915 No. 732.

${ }^{30}$ Usulan Perubahan RUU KUHP Hasil Musyawarah, p. iii.

${ }^{31}$ Ibid., p. iv. 
draft. In general parlance, there are at least three principles of Islamic penal law submitted in the draft, namely: first, introducing the concept of qishäsh, diyat (blood money) and kafarah (fine), especially to those crimes related to bodily harms; second, permeating the concept of

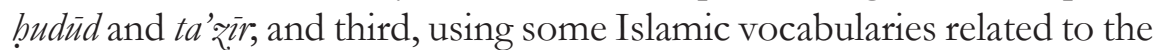
penal law, such as diyah mugholladzoh, diyah mukhoffafah, irsyu, etc. Those are the three core concepts that had been infused into the draft of the penal law. Although the process of the instalment of the Islamic penal law theories into the draft was heralded by huge debate and rejoinders among those Ulama in the meeting, they could finally come to the same level on the ideal of Islamic penal law implementation in the public lives of the Indonesian people. The enormity of those Ulama could be seen in the process of the discussion of each topic emanated in the draft. In so doing, there were three steps they had taken in the meeting: first, the discussion was started initially through separated three commissions based on the topics of the draft; second, general panel discussion for the whole participants to gather all Islamic ideas to be submitted into the draft; and finally the result of the discussion in step two was taken to a limited forum consisting of a smaller number of participants to reformulate the final result of the meeting. We can see therefore that the review was done preceded by careful discussions, debates and rejoinders among those in the meeting to arrive at the epitome objective, namely permeating the ideas of Islamic penal law into the draft of the national penal code.

Reading the review of the draft, someone should not forget the three classifications of crimes as taught in the Islamic penal law, i.e., hudūd, qișass and $t^{\prime}$ 'zir go beyond the basic theory of penal law explained in many classic books of fiqh jinayya. There were no less than 17 figh books recorded to have been chosen by the participants of the meeting as a resource of their theoretical basis. Those books were: (1) Hasyiya Tarshikh al-Mustafidin bi Tanshikhi Fatḥ'l-Mu in by Syaikh Zainuddin ibn 'Abdil 'Azīz al-Malibari; (2) I'ānatu'l-Ṭälibin by al-'Allāma al-Fāọil al-șāliḥ al-Kāmil al-Sayyid Abū Bakr; (3) Bulüghu'l-Marām by Ibn Hajr al-Asqalānī; (4) Suqütu'l- 'Uqüba fì'l-Islām by Jabr Maḥmūd al-Fuḍaila; (5) Al-Fiqhu'l-jinā'i fìl-Isläm by 'Amir 'Abd al-'Azīz; (6) Al-Mughñ̄ by Muḥammad 'Abd Allāh ibn Aḥad ibn Mạ̣mūd 
ibn Qudāma; (7) Al-Tasyrǐu'l-Jināı̀ al-Islāmī by 'Abd al-Qādir Awda; (8) Hashiya Raddu'l-Mukhtār by Khotimah al-Muhaqqiqin Muhammad Amin al-Syahir ibn 'Abidīn; (9) Kifāyatu'l-Akhyār fì Halli ghäyatil-Ikhtișār by AlHusaynī ad-Dimashqī al-Shāfīī; (10) Fiqhu's-sunna by Sayyid Sābiq; (11) Sharb Marqoti Sudi al-Tașdiq fi Sharh Sullamu't-Tawfí by al-'Ālim al-Fadil Al-Shaikh Muhammad Nawawī; (12) Hashiya I'änatut-Täalibin by al-Sayyid Abū Bakr; (13) Al-Takmila al-Majmū' Sharḅu'-Muhadhdhab by al-Imām Abu Zakariyya Muhyidin Sharaf al-Nawāwī; (14) Fì Džilāl al-Qur'ān by Sayyid Qutb; (15) Al-Muhadhdhab fì Fiqh Madhäbibish-Shäfìi by Al-Shaikh al-Jāhid al-Muwaffaq Abū Isḥaq Ibrāhim ibn 'Ali Yusūf; (16) Bujayrimi 'Alì al-Khätib by Al-Fairuzzabadī al-Sirajī al-Sheikh Sulayman al-Bujayrimi; (17) Al-Futuhät al-Ilähìyah bi Tawdīḩ Tafsir al-Jalalayn li al-Daqiq al-Khafiyyah by Sulayman Ibn 'Umar al-Ujayl al-Syāfi'ī.

Those traditional Arabic books were used as material and methodological resources in the process of inserting Islamic penal values into the draft of the national penal law. Although one may remain doubtful whether those Arabic references are fit with the modern philosophy of punishment wrought about in the new national draft, the use of the old Islamic references aptly reflected their sincerity in the struggle of penal law Islamisation. At least, the reading of the old figh and tafsir books is what the symbol of Islamisation is all about, irrespective of the epistemological problems lingering the process. Despite those long and industrious efforts done by Ulama and GARIS protagonists, the meeting itself was finally ended in despair since the government, in this case, the Ministry of Law and Human Rights has never in reality taken great care with the draft of the penal law. The draft is up to now not brought yet to the People Assembly (Dewan Perwakilan Rakyat), the first step to open the hope of the penal law Islamisation program is thus no more than a hollow imagination.

Irrespective of the unsuccessful political supports, the movement to Islamize penal law system in the country has been much talked about in the circle of legal academics and national jurists in the country. The main problem haunting the Islamisation cannot be separated from the fact that Islamic penal law is fulfilled by traditional penal ideas in which corporal punishment is so much colouring the system. This is also clear in what expressed in the proposal to improve the government draft substantiated 
during the Ulama meeting above where corporal punishments remain to be the central method of punishment, besides fine and penitentiary. This means that most Muslim experts invited to the meeting were mostly of those with a traditional and orthodox understanding of penal law and tended to view the Islamic penal tradition as not receptive towards modern views of punishment. Especially in dealing with such crimes related to sexual matters as an illicit sexual relationship, rape, homosexuality or any other 'religious' criminalities such as religious blasphemy, religious deviations, etc., the participants of the meeting remained to stick with traditional figh jināyah. It appears therefore that the main mission of the review of the national penal law draft does not depart from the old idea to bolster traditional views of Islamic penal law into the national criminal law system. This was certainly done ignoring the values of religious plurality and multiculturalism deep entrenched within the lives of the people. Imposing certain particular penal tradition in such a plural society will certainly ruin the whole structure of the country.

\section{Contra-Christianization}

This issue arose since the early years of GARIS establishment in Cianjur. Indeed, it was a hot topic throughout West Java until about the first decade of the year 2000 to which all Muslim organisations usually put their much interest. Their main concern here was that the program of Christianization (in this case understood more like the activity of Christian proselytization) was usually done in the midst of Muslim majority so as to easily ignite conflicts between Muslim and Christian followers. According to Hernawan, the biggest problem following the Christianization programs is at least twofold: First, the common ignorance to national regulations dealing with religious entities, specifically the Jointly Ministerial Regulation (Surat Peraturan Bersama) between Minister of Religion and Home Minister No. 8 and 9 of 2006 regulating the basic rule of religious preaching in the country; and second, the horizontal schism between people with different religious compliance, i.e., Muslims and non-Muslims (Christians). ${ }^{32}$ The point of the struggle is here laid in the efforts to defend the rights of every Muslim not to be persuaded to follow other religious beliefs. In other words, Christianization is

${ }^{32}$ Hernawan, interview (8 May 2009). 
understood here essentially as an effort done to influence people to follow the teaching of Christianity, irrespective of the fact that the target is an individual or a group having already certain religious submission. This is certainly seen as transgressing the basic tenets of Islamic law to which all Muslims should hold steadfastly in their everyday lives.

That is exactly the main reason for GARIS to wage the hard movement to challenge the Christianization in all its forms. In their view, Christianization transgresses the right of every Muslim to maintain their belief and thus to transgress their basic human rights to which the state and every citizen, regardless of their belief, should recognise. And thus, according to GARIS, the movement of anti-Christianization is par excellence part of legal Islamisation to which they will always put all efforts in the field to succeed it. However, in practice, it is not clear what kind of activities properly called as 'Christianization' since the boundaries in many cases are blurred between the activity of religious propagation and religious implementation. The experience of GARIS in holding the struggle of anti-Christianization clearly shows such bewilderment. In the field, the attack of GARIS members towards Christian denomination was often undertaken under the name of challenging Christianization, with the result that the Christian rights for practising their religious teachings were molested.

One of GARIS biggest movements of anti-Christianization was done in July 2007. On that day, thousands of GARIS members were involved in attacking a Christian valley, called Lembah Karmel, which is kind of religious compound usually used as a place for spiritual retreats and praying by Christians from many places around Cianjur. The sudden visit of many GARIS members to this valley was so surprising as around 2,500 followers of the Christian denomination were in the preparation of holding an international conference and alumni meeting. There was almost a massive fighting between the two groups since GARIS forced the Christians to halt the meeting and cancel all programs already planned by the committee. One GARIS member explained that the action was done rightly to close down the Christianization programs done by a certain Christian group in that valley. ${ }^{33}$ They believed to the issue that the compound had been used for quite long time to create a comprehensive

${ }^{33}$ GARIS member, interview (10 Jul 2013). 
program of Christianization throughout Indonesia. Although the source and validity of the problem are not clear, they feel plausible enough to attack the valley sporadically. The violence was successful finally to stop all activities in the place. And hundreds of members of the Christian denomination felt mocked and physically abused by the treatment of the GARIS members.

Analysing the case of the Karmel attack, one will see how violent approach has been used effectively as a means to pave the way for succeeding any GARIS programs of Islamisation. Although it remains unclear whether the Christian group in the Karmel Valley had organized a certain project of Christianization, ${ }^{34}$ the attack had already established certain painful feeling among Christian in that area. One informant expressed this feeling of an uncomfortable fate of Christian society as a minority group living in the midst of the majority Muslim community of Cianjur. ${ }^{35}$ Their rights as religious people having so much passion for practising their religious belief have been truncated with such violent actions. This seems the unavoidable consequences of such a choice of method, where violence becomes the basic language of the struggle, the project of Islamisation could become a means of oppression of the majority towards the minority.

What is more interesting is the philosophical underpinnings involved to back up such a program of anti-Christianization. According to GARIS, Christianization done in a country such as Indonesia where Muslims are the majority of the population transgresses, in essence, the messages behind the rule explained in the Jointly Ministerial Regulation (Surat Peraturan Bersama) between Minister of Religious Affairs and Home Minister No. 8 and 9 of 2006 on the procedure of building a worshipping place. As regulated in the Ministerial Regulation, the building of the place should be based on the need of the people in the place concerned. This would mean that the building of the worshipping place should come in line with the general purpose of maintaining the harmony of the society as well as not disturbing public peace and order. That is why that to assure those conditions, the construction of the place should be supported by

${ }^{34}$ One Christian informant told that the issue of Christianization done by the group in Karmel valley is certainly not found in reality.

${ }^{35}$ A figure, interview (10 Aug 2009). 
the evidence that there are at least 90 members of the concerned religious group and 60 local residents of another religious belief agreed with such a building, besides the recommendation of the local government. ${ }^{36}$

As far as the conditions of the Christian group at Karmel are concerned, the Christian activities at the Valley are certainly not capable upholding those government regulations, ${ }^{37}$ even though it was also unclear whether the Valley was built by those conditions as emanated by the regulation. The main point of Hernawan's argument was very clear here that the message behind the regulation should be understood as a rule that any religious activities should not be undertaken if local people do not support them. Thus, Christianization done in the midst of the majority Muslim population of Cianjur is just an illegal activity if it is not backed up by people of the place, the transgression should thus be interpreted as disobeying the literal meaning of the regulation. Hernawan here seemed to stress that beyond the inconceivability for Muslims to support the Christianization, the project is in itself contrary to Islamic teachings as it will give detrimental effects on the existence of Islam in the place, according to which GARIS has the duty to challenge. ${ }^{38}$

In this case, GARIS understood legal Islamisation as a means to response to the need of every Muslims feeling safe of a possible attack from non-Muslims endangering their beliefs and religious teachings. Christianization is an attack on the belief of Islam since its main purpose is to persuade Muslims to leave their religious affiliation. Understanding Christianization in this way would automatically lead to a

${ }^{36}$ According to the Jointly Ministerial Regulation between Minister of Religious Affairs and Home Minister No. 8 and 9 of 2006, Articles 14-16, constructing places of worship should comply with the permission required for construction in general. At the same time, it should also follow a number of the technical conditions, namely, first, an obligation to obtain the permission of at least 90 members of their own religious group, approved by a local official; second, an obligation to obtain the support of at least 60 local residents (of another religion), approved by the head of the village; third, obtaining a written recommendation supporting the construction from the head of regency/city office of the department of religion; and, fourth, the written recommendation from the regency/city branch of the FKUB. On the Regulation see at http://kemenag.go.id/ file/dokumen/PERMEN906.pdf. Also, Melissa Crouch, 'Regulating Places of Worship in Indonesia', pp. 107-114; Melissa Crouch, Law and Religion in Indonesia, pp. 105-106.

${ }^{37}$ Chep Hernawan, interview (7 Oct 2013).

${ }^{38}$ Ibid. 
serious responsibility of every Muslim to take part confronting it in any means possible. In the field, it is not clear however whether Christian group in Karmel valley has been proven to organise particular project of Christianization as accused by GARIS or they simply practice their own religious teachings. The problem is that most people in the grassroots are not capable of distinguishing religious propagation from religious implementation since the border between the two has indeed so blurred inasmuch as that they do not have any interest to investigate the accusation vigilantly. Verification has therefore never been held to disclose the truth, but this might be deliberately designed to stir people to the belief that Christianization has happened in the society, the task of GARIS as a guardian of Islamic law has therefore been valuable of support. Beyond the polemic, whether Christianization had happened, the theoretical underpinnings to back up the movement of anti-Christianization might be acceptable but the sporadic violence resulted from such a struggle is what everyone needs to put their concern.

\section{Challenging Abmadiyah}

Since its early activities, GARIS has put so much concern on the case of Ahmadiyah in Indonesia. This is what can be seen from many of GARIS' responses since the debate on Ahmadiyah arose heatedly in the country circa 2005. In some occasions, Hernawan explicitly expressed his willingness to focus GARIS' Islamisation program on the efforts to demolish Ahmadiyah movements in Cianjur and its surrounding areas. This kind of admonition was then proven by GARIS's attack to some Ahmadiyah compounds on September 19, 2005, destroying four villages: Penyairan, Cicakra, Neglasari and Ciparay. It was recorded that 43 houses, four mosques, five small groceries and other uncountable kinds of stuff were destroyed in one attack on that day. ${ }^{39}$ GARIS involved hundreds of members in this attack and sporadically left physical as well as psychological burdens to the Ahmadiyah followers. Many have indeed realised that this kind of attack would most possibly be inflicted to Ahmadiyah group since, with its zero-tolerant character, GARIS would consistently threaten all other Muslim groups and denominations viewed as not going in line with the mainstream of Sunnite Islam.

\footnotetext{
${ }^{39}$ Hasani, Radikalism Agama di Jabodetabek \& Jawa Barat, p. 128.
} 
What is interesting to note is that GARIS escalated movements of anti-Ahmadiyah was so much supported by political constellations of Cianjur around the end of 2005. Wasidi at the time was about to run forward for his candidacy as a regent in the second term. He certainly needed to get as many voters as possible for the sake of succeeding his campaign; and with this interest, it was not a surprise to see his many efforts to approach Muslim groups and organisations in the city. And one of the best issues to attract supports was that of Ahmadiyah. In other words, attacking Ahmadiyah at the time of Cianjur's unstable politics was possibly not the mere issue derived from certain religious interpretations but more a reflection of specific political needs. Seen from that perspective, we can say that viewed from a micro level, GARIS action to attack Ahmadiyah groups in a number of places in Cianjur was coincident with the political situation of the regency, especially when experiencing such a shaky political shifting from the old to the new leadership. Wasidi did not want to miss the chance. He cleverly tried to win the heart of many Muslim constituents in the city by promulgating officially a General Letter of Decision (Surat Keputusan Bersama), which he claimed to have been made with the support and agreement from Indonesian Council of Ulama (Majlis Ulama Indonesia, MUI) and about 40 mass organisations in Cianjur. The point of the Letter was very clear on the banning of the existence of Ahmadi group throughout Cianjur. What is interesting is that the Decision Letter was issued just ten days after the event of GARIS attack in a number of Ahmadiyah compounds in Cianjur; thus reflecting so much the concerted design of demolishing the group with state officials and non-state actors worked hand in hand.

Yet, what is no less important is the macro perspective used in this kind of issue where religious, political identity becomes the centre of gravity. GARIS determination to attack Ahmadi group was gaining its momentum in July 2005 when MUI had before officially declared Ahmadiyah as a deviated religious entity through their fatwa. Although this fatwa does not require Muslims in the country to attack or knock down many institutional apparatuses of Ahmadiyah, the declaration coming from such a prestigious institution (to which GARIS has so far relied much on their religious opinions) worked as a perfect psychological backup for their violent movement. In this concern, what MUI has done 
was not by commission taking part in such a movement to attack Ahmadiyah brutally and sporadically but by omission giving support to any kinds of movements directing to challenge Ahmadiyah and their existence in the country.

One may wonder what the reasons that could steer such a mass organisation as GARIS to passionately attack Ahmadiyah, considering that the latter is a Muslim group as well. The answer seems to derive from the historical fact of the persistent conflict between Sunnite Islam and Ahmadi group on the issue of prophecy. In the view of Sunnite Muslims, the belief in the next prophecies after the prophet Muhammad is what makes Ahmadiyah considered as a group deviated from the mainstream Islam. The belief as such would lead to an understanding that besides the Sunnab of the Prophet Muhammad that could serve as the source of Islamic law, there might still be another Sunnab to be treated the same as well. This certainly detriments the basic legal tenet of Islam; the conflicting attitude of GARIS towards Ahmadi group is, therefore, a perennial one and all is based on their theological foundations believed to be established by a certain rigid understanding of the religion. Since challenging this group is departed from the knowledge of the need of every Muslim to uphold their belief and save the true teaching of Islam, in the attack towards the Ahmadi group, GARIS believes to have involved them in the process of saving Islam from many deviated teachings that will destroy Islam from within. Legal Islamisation understood in this project is thus laid in the point of the struggle to save the real basic source of Islamic law, i.e., the Sunnab of the last prophet Muhammad, to which no one after him can serve as such.

It is worth noting that the harsh attitude of GARIS towards Ahmadiyah is not without supports from other Muslim mass organisations in Cianjur. At least, no one of them showed their concern or apprehension when GARIS attacked Ahmadiyah compounds, even though everyone knows that it brought many casualties. We can say therefore that the state quasi-supports, at least what was shown from the decision of the Cianjur regent, as well as those expressed in the MUI's fatwa, had given a result in the backup, both implicitly and explicitly, coming from the common mass Muslim organisations in Cianjur. The GARIS movements of anti-Ahmadiyah could be said to have been substantiated since its 
early phase by political as well as theological underpinnings. Although many had disagreed with the violent method used in the movement, they did not show their criticism. People in the city had just witnessed the deteriorating fate of Ahmadiyah as a marginalised minority Muslim group in the midst of the silent majority Sunnite Muslim society.

Interestingly, GARIS's project of anti-Ahmadiyah movements was undertaken not only in Cianjur and its surrounding area but outside the regency as well. This seemed related to the long-term mission of the organisation to spread its programs of Islamisation outside Cianjur regency. That was what appeared when GARIS sent a lot of its members to attend the public hearing session in the process of the judicial review of the Law No. 1 of 1965 on religious blasphemy in the Constitutional Court in Jakarta. Although the hearing was initially designed to specifically debating whether the Law transgresses the principle of religious freedom espoused in the Constitution, it turned to become such kind of arena for majority Muslim organizations to back up the idea to maintain the Law No. 1 of 1965 as they saw it as not contravening the principle of religious freedom. They even used the session to substantiate their defensive arguments against many cases of defamations directed to Islam, an evidence of an alarming situation for the Constitutional Court not to accept the idea of reviewing the Law as it would mean to possibly destruct Article 1, which explicitly forbids the acts of religious blasphemy. ${ }^{40}$ This thinking came mainly from Muslim organisations in the country believing in the need to maintain the Law so that the sacredness of religious teachings can be protected by the state. They were also arguing that the judicial review would only result in the situation of legal vacuum --at least until the new law is successfully promulgated-- so as to lead people undermining the message contained in the Article 1 of the Law, and freely denigrating religious teachings.

GARIS understood that attending the hearing session of the judicial review is part of their struggle to save Islam from many new teachings deviated from the true understanding of the religion. And one of such deviated groups was certainly the Ahmadi whose teachings had been

${ }^{40}$ The discussion on the judicial review of the Law No.1/1965 at 'Talks on the Blasphemy Law: Human Rights vs. Mainstream Islam, An Off Stream Presentation by M. Isanegri', KITLV, Leiden University, the Netherlands, June 24, 2010. 
seen by majority Ulama to have departed far beyond the true teaching of Islam. GARIS believes that Ahmadi's teaching of the prophecy after the Prophet Muhammad is an evidence of their deviation from the true Islam so that any activities done to propagate their teaching will automatically fulfil the criteria of religious blasphemy as emanated in Article 1 of the Law. That was why GARIS sent a lot of members to attend the hearing session in the Constitutional Court. Although no one of GARIS people was invited to speak in front of the hearing forum, their presence can deliberately be denoted as showing a significant support to the issue of anti-religious blasphemy. A big number of the members were sent to Jakarta by bus specifically rented for that purpose; their presence in front of the Court's building as well as in the room during the hearing session through displaying the banner attacking the opponent views, raising their voice or threatening others seen as having different opinion were just examples of the method to demonstrate the struggle. In this way, what was believed was that through such an extra-legal movement, GARIS could influence the Court in the process of making the decision of the issue in concern, although many may view it as too harsh and could be trapped into criminal contempt. ${ }^{41}$

In this issue of Ahmadiyah, it is clear that GARIS has used their mission of legal Islamisation as a leeway to express their understanding of Islam and to act offensively towards others having a different opinion. The meaning of legal Islamisation thus works here unlimited to any activities to propagate Islamic legal implementation in everyday lives of the people but to include also any means to pave the way for certain mainstream interpretation of Islamic law (or Islam in general) accepted as the sole value in the society and accordingly marginalising others. This might be the consequence of Islam itself as a religion with multifaceted values. As the understanding of Islamic law can also be varied, the project of legal Islamisation can be brought into certain meaning in conjunction with the views embraced by the agent of the Islamisation itself. In other words, considering GARIS as one of the proponents of Sunnite Islam, undertaking the attack toward Ahmadiyah might be viewed as coming in line with the campaign to propagate the 'true' Sunnite understanding

${ }^{41}$ Criminal contempt, in this case, is understood as acts disrespectful of the court or its processes. 
of Islam itself, according to which any opponent interpretations could be categorized as heresy to Islam and thus suitable as an object of the harsh Islamisation movements.

\section{E. Concluding Remarks}

In the present discussions about Islamisation of legal systems, the movement has usually been understood to occur in many Muslim-majority countries since the last quarter of the twentieth century, encompassing at least three legal domains working as gateways for the incorporation of Islamic law into certain legal systems of contemporary states. First, Islamic law is understood as a constitutional standard and aspiration; second, as a source of substantive law; and third, as 'a result of the operation of rules of international private law'. ${ }^{42}$ Yet, particularly in many Western secular countries, the struggle of legal Islamisation has also appeared in the form of alternative dispute resolutions (ADR) in which Islamic substantive law is implemented outside the domain of official legal institutions. ${ }^{43} \mathrm{~A}$ number of methods have thus been created therefore to assure that the legal teachings of Islamic law can be implemented and inserted into the modern legal system of the country.

In the case of Indonesia, seen from the perspective of legal theory, the scope of the struggle of legal Islamisation can be characterised as focusing on three different levels: First, national (higher) law, where the movement is focused on the Islamisation of the constitution and fundamental laws of the country. Majlis Mujahidin Indonesia (MMI) seems to stress on this level, such what we can see from their proposals for amending the 1945 Constitution and Basic Penal Law of the country outlined in the early 2000s. Second, local law. The struggle at this level is usually centred on the Islamisation of the state by-laws, touching the issues emanated in the local regulations. Komite Persiapan Penegakan Syariah Islam (KPPSI) in South Sulawesi is the best example in this concern, where movements are focused on building Islamic regional regulations working in certain regents or districts. And the third, law in general

${ }^{42}$ Martin Lau, "The Re-Islamisation of Legal Systems", in The Ashgate Research Companion to Islamic Law, ed. by Rudolph Peters and Peri Bearman (England and Burlington: Ashgate, 2014), p. 235.

43 Ibid., p. 234. 
meaning, i.e., the law used in a rather loose term incorporating any ideas of normative values related to all aspects of life, not only the ones managed through the state laws. GARIS here seems to base their struggles on the understanding of law not confined only to the ones attached to the state but broader and practical aspects of law in its relation to everyday lives of the people. Thus, if the other organisations such as MMI and KPPSI above focus their interests in the formal (state) law of the country, either in the national or regional levels, GARIS seems to plunge themselves into the realm of non-formal laws.

Reading carefully the paragraphs above, one will see how the idea of legal Islamisation is carefully moulded in the field to make it so fluid and adequate to accomplish a purpose. Islamisation of law cannot be defined here solely based on the perspective of Westphalian view where a law is seen from the established institution of the state only. Law can indeed come from the state but certainly not necessary. This gives a consequence that to understand Islamisation of law we should vigilantly see how people in general or the actor of the Islamisation, in particular, comprehend the meaning of the law itself. This current study has tried to show that as one example of non-state Muslim organisations concerned with the issue of the Islamisation, GARIS has leniently understood the law in a wider scope, encompassing not only the state law but also nonstate normative orderings. If this is correct, the Islamisation of law done by this mass organization involve not only the effort to bring the state legal system in par with Islamic values but also any struggle to pave the way for the implementation of Islamic teachings in general in everyday lives of the people, either related to (formal) law or not.

The three examples of GARIS' Islamisation programs as explained above show very clear how Islamic law emulates all aspects of life, from the matters of belief such as religious conversion, proselytization and abiding by certain madhhab - in essence, personal matters, to such a big public matter as penal law system working in the country. One might view that submitting to a certain school of law in Islam or certain religious belief is the basic human right each people should uphold, but GARIS might not follow this perspective due to their understanding of Islamic law as an all-encompassing legal tradition dealing with all aspects of life. There is no need to separate the realms of the public from a personal 
law, as all can come under one umbrella of the religious law. Based on the prophetic tradition explicating all Muslims to challenge any wrongdoings found everywhere -- seen as the expression of the religious belief--, GARIS has a valid theological basis to embark on their Islamisation programs in any means whatsoever.

Thus the organisation can see itself as having an obligation to tackle any cases perceived as transgressing the basic tenets of Islam. This is what seems to ignite many conflicts in the society since their monolithic approach in understanding Islamic law will certainly invite others to confront. And violence would thus not be an unusual impact involved in the struggle. No doubt, this can be excellent modus operandi for many members of GARIS to trap themselves transgressing the principle of human rights in undertaking such projects of Islamisation. In the name of certain legal ideology, GARIS can embark openly to challenge violently what they view as wrongdoings due to the mere differences in opinion of certain laws or faith. GARIS has also practically judged certain legal opinions as going astray since their disjunction with the mainstream views in general. This kind of attitude is what makes GARIS to be considered as one of the most radical local Muslim groups in West Java consistently transgressing the principles of religious tolerance. Any acts of violence, distinction, restriction and also preference showed in the three projects of penal law Islamisation, anti-Christianization, as well as an anti-Ahmadi group, have fulfilled the criterion of intolerance initiated by the Declaration on the Elimination of All Forms of Intolerance and Discrimination Based on Religion or Belief. Those acts were done due to certain theological understanding believed to be based on Islamic teachings emanated in the sacred texts, regardless of human rights values and fundamental freedoms believed to be the basis of the democratic society built in the country. As a consequence, the acts of intolerance will certainly result in the feeling of discord and awkwardness in the midst of people where the Islamisation projects are undertaken.

Furthermore, one may need to be aware also that since National Law is idealized to include all Indonesian people regardless of religion, skin color, ethnic, race, etc., the Islamisation projects as done by GARIS may run in contradiction to the epistemology of the law and legal system built in the plural society of Indonesia. In the current situation, 
the problem we encounter is how to consolidate the idea of uniformed (united) national law and the message behind the local movement of Islamisation. While National Law is imagined as a general law to include any particularities existing in the country, the idea of legal Islamisation is embarked by particularism and localism to which favouritism works as the main logic of the struggle. This is what seems unanswered since what is appearing now is not the theoretical predicament of such a process but its political impacts, as legal Islamisation is more sensed as a political movement than that of law. 


\section{BIBLIOGRAPHY}

A/RES/36/55. Declaration on the Elimination of All Forms of Intolerance and of Discrimination Based on Religion or Belief, 10 Feb 2017, http://www. un.org/documents/ga/res/36/a36r055.htm, accessed 10 Feb 2016.

Buehler, Michael, "Shari'a and Social Engineering: The Implementation of Islamic Law in Contemporary Aceh, Indonesia by R. Michael Feener (review)", Indonesia, vol. 98, no. 1, 2014, pp. 147-52 [http:// dx.doi.org/10.1353/ind.2014.0014].

Cowan, J. Milton, Arabic-English Dictionary: The Hans Wehr Dictionary of Modern Written Arabic, 3rd edition, Ithaca, NY: Spoken Language Services, 1976.

Hasani, Ismail, Radikalism Agama di Jabodetabek \& Jawa Barat: Implikasinya terhadap Jaminan Kebebasan Beragama/Berkeyakinan, Jakarta: Publikasi Setara Institute, 2001.

Lau, Martin, "The Re-Islamisation of Legal Systems", in The Ashgate Research Companion to Islamic Law, ed. by Rudolph Peters and Peri Bearman, England and Burlington: Ashgate, 2014.

Lindsey, Timothy, Islam, Law and the State in Southeast Asia, vol. I, London and New York: I.B. Tauris, 2012.

Lukito, Ratno, Legal Pluralism in Indonesia: Bridging the Unbridgeable, London and New York: Routledge, 2013.

Makruf, Jamhari and Iim Halimatussa'diyah, Shari'a and Regional Governance in Indonesia: A Study of Four Provinces, SSRN Scholarly Paper, no. ID 2459826, Rochester, NY: Social Science Research Network, 2014.

Platzdasch, Bernhard, Islamism in Indonesia: Politics in the Emerging Democracy, Singapore: ISEAS Institute of Southeast Asian Studies, 2009.

Price, Daniel E., Islamic Political Culture, Democracy and Human Rights: A Comparative Study, Westport, Connecticut: Praeger, 1999.

Suprapto, Rohmat, Syariah "Kacapi Suling” \& Syariat Progresif: Pergulatan Politik dan Hukum di Era Otonomi Daerah, Yogyakarta: Samudra Biru, 2011.

Usulan Perubahan RUU KUHP Hasil Musyawarah 'Alim Ulama se Jawa Barat yang Diwakili oleh Kabupaten Sukabumi, Cianjur, Garut, Tasikmalaya, 
Islamization as Legal Intolerance

Cianjur, 10-18 Ramadan 1422--26 Nopember-3 Desember 2001, Cianjur, 2001. 